\title{
PENYELESAIAN KASUS TANAH DENGAN DENGAN SURAT TANAH LEBIH DARI SATU ( SERTIFIKAT GANDA) DI KOTA PALANGKA RAYA
}

\author{
LAND CASE SETTLEMENT WITHLAND LETTER \\ MORE THAN ONE(DOUBLE CERTIFICATE) IN PALANGKA RAYA CITY
}

Eny Susilowati, S.H., L.LM

Universitas PGRI Palangka

Raya, Palangka Raya,

Kalimantan Tengah, Indonesia

*email: email correspondence

\section{Kata Kunci:}

Penyelesaian I

Kasus Tanah2

Surat Tanah Lebih Dari Satu3

Keywords:

Settlement $I$

Land Case2

More Than One Land

Certificate3

\begin{abstract}
Abstrak
Tanah merupakan suatu kebutuhan dari setiap warga negara saat ini. Kebutuhan akan tanah terlihat dari antusias setiap orang akan memperoleh dan mempertahankan tanah yang mereka inginkan dan mereka miliki. Tanah yang merupakan karunia dari Tuhan Yang Maha Esa, memiliki nilai yang sangat tinggi secara ekonomi, sosiologi, maupun secara derajat seseorang ditengah masyarakat. Seiring perkembangan akan kebutuhan tanah disaat ini, bersamaan dengan itu juga berkembang pula regulasi-regulasi atau aturan yang mengatur bagaimana cara memperoleh serta mempertahankan tanah tersebut. Pemerintah yang berwenang mengeluarkan segala jenis aturan tersebut merasa harus untuk mengeluarkan peraturan-peraturan tentang pertanahan, maka dibentuklah Undang-undang Pokok Agraria yaitu Undang-undang No. 5 Tahun 1960. Namun peraturan-peraturan tersebut belum sepenuhnya melindungi para pemegang hak atas tanah. Karena besarnya nilai tanah tersebut, sering menimbulkan sengketa pertanahan. Metode pendekatan yang digunakan dalam penelitian ini menggunakan metode penelitian hukum empiris, yaitu penelitian yang menitik beratkan terhadap data primer. Faktor yang menyebabkan surat tanah menjadi ganda adalah kurang telitinya panitia ajudikasi dalam mengumpulkan data fisik tanah yang dimohonkan pendaftarannya, sering mengakibatkan terjadinya overlapping (tumpang tindih) surat tanah. Selain hal tersebut kurangnya pengetahuan masyarakat tentang prosedur pembuatan surat tanah, sehingga dimanfaatkan oleh oknum perangkat desa atau pejabat badan pertanahan dengan memalsukan data - data yang di perlukan dalam rangka pendaftaran tanah.Penyelesaian sengketa yang dapat dilakukan di Badan Pertanahan Nasional (BPN) adalah memfasilitasi dalam Mediasi/Musyawarah. Badan Pertanahan Nasional berperan sebagai tempat mediasi atau tempat menyelesaikan sengketa secara kekeluargaan tanpa melewati pengadilan.
\end{abstract} \begin{abstract}
Land is a necessity for every citizen these days. The need for land is reflected in the enthusiasm of everyone to acquire and maintain the land they want and have. Land, which is a gift from God Almighty, has a very high value economically, sociologically, and in terms of a person in society. Along with the development of the current need for land, at the same time also develop regulations or rules governing how to acquire and maintain the land. The government, which is authorized to issue all kinds of regulations, feels compelled to issue regulations regarding land, so the Basic Agrarian Law, namely Law No. 5 of 1960. However, these regulations have not fully protected land rights holders. Due to the large value of the land, it often creates land disputes. The approach method used in this study uses empirical legal research methods, namely research that focuses on primary data. The factor that causes double land certificates is the lack of accuracy of the adjudication committee in collecting the physical data of the land being applied for registration, which often results in overlapping land certificates. Apart from this, there is a lack of public knowledge about the procedures for making land certificates, so that village officials or land agency officials have falsified the data needed for land registration. The settlement of disputes that can be carried out at the National Land Agency (BPN) is facilitating Mediation / Deliberation. The National Land Agency acts as a place for mediation or a place to resolve disputes amicably without passing through the court.
\end{abstract}

Published April 2021

Accepted

Maret 2021

(C) 2021 The Authors. Published by Institute for Research and Community Services Universitas Muhammadiyah Palangkaraya. This is Open Access article under the CC-BY-SA License (http://creativecommons.org/licenses/by-sa/4.0/).

\section{PENDAHULUAN}

Tanah merupakan kebutuhan hidup manusia yang sangat mendasar. Manusia hidup serta melakukan aktivitas di atas tanah sehingga setiap saat manusia selalu berhubungan dengan tanah dapat dikatakan hampir semua kegiatan hidup manusia baik secara 
langsung maupun tidak langsung selalu memerlukan tanah. Begitu pentingnya tanah bagi kehidupan manusia, maka setiap orang akan selalu berusaha memiliki dan menguasainya. Dengan adanya hal tersebut maka dapat menimbulkan suatu sengketa tanah di dalam masyarakat.

Tanah mempunyai peranan yang besar dalam dinamika pembangunan, sehingga dalam UndangUndang Dasar 1945 pasal 33 ayat 3 disebutkan bahwa "Bumi dan air dan kekayaan alam yang terkandung didalamnya dikuasai oleh negara dan dipergunakan untuk sebesar-besar kemakmuran rakyat”. Ketentuan mengenai tanah juga dapat kita lihat dalam UndangUndang Republik Indonesia Nomor 5 Tahun 1960 tentang Peraturan Dasar Pokok-Pokok Agraria atau yang biasa kita sebut dengan UUPA. Timbulnya sengketa hukum yang bermula dari pengaduan sesuatu pihak (orang/badan) yang berisi keberatan-keberatan dan tuntutan hak atas tanah, baik terhadap status tanah, prioritas, maupun kepemilikannya dengan harapan dapat memperoleh penyelesaian secara administrasi sesuai dengan ketentuan yang berlaku.

Tanah juga mempunyai arti penting bagi kehidupan bangsa indonesia, hal ini karena Negara Indonesia merupakan negara agraris, sehingga setiap kegiatan yang dilakukan oleh sebagian besar rakyat indonesia senantiasa membutuhkkan dan melibatkan soal tanah. Bahkan sebagian besar masyarakat, tanah dianggap sebagai sesuatu yang sakral, karena disana terdapat simbol status sosial yang dimilikinya. Maka dari penjelasan diatas tanah dibutuhkan oleh banyak orang sedangkan tanah jumlahnya tidak bertambah atau tetap, sehingga tanah yang tersedia tidak mampu lagi memenuhi kebutuhan yang terus meningkat terutama kebutuhan akan tanah untuk membangun perumahan sebagai tempat tinggal, untuk bercocok tanam atau pertanian, serta untuk membangun fasilitas umum dalam rangka memenuhi tuntutan tehadap kemajuan di berbagai bidang kehidupan.
Untuk mencapai cita-cita Negara tersebut diatas, maka dibidang agraria perlu adanya suatu rencana (planning) mengenai peruntukan,penggunaan dan persediaan bumi, air dan ruang angkasa untuk berbagai kepentingan hidup rakyat dan Negara. Secara konstitusional, Undang-Undang Dasar 1945 dalam Pasal 33 ayat (3) menyatakan bahwa "bumi, air, ruang angkasa serta kekayaan alam yang terkandung di dalamnya dikuasai oleh Negara dan dipergunakan untuk sebesar-besar kemakmuran rakyat”. Dari ketentuan dasar ini, dapat diketahui bahwa kemakmuran rakyatlah yang menjadi tujuan utama dalam pemanfaatan fungsi bumi, air dan ruang angkasa serta kekayaan alam yang terkandung di dalamnya.

Mengingat arti pentingnya tanah bagi kelangsungan hidup masyarakat, maka diperlukan peraturan yang lengkap dalam hal penggunaan, pemanfaatan, pemilikan dan perbuatan hukum yang berkaitan dengan hal tersebut. Semua ini bertujuan untuk menghindari persengketaan tanah baik yang menyangkut pemilikan maupun perbuatan-perbuatan hukum yang dilakukan pemiliknya, maka dari itu dibuat Undang-Undang Nomor 5 Tahun 1960, tentang Peraturan Dasar Pokok-pokok Agraria yang biasa disebut Undang-Undang Pokok Agraria (UUPA) mengisyaratkan bahwa tanah itu pada tingkatan tertinggi dikuasai oleh Negara sebagai organisasi seluruh rakyat. Dalam rangka menjamin kepastian hak dan kepastian hukum atas tanah, Undang-Undang Pokok Agraria (UUPA) telah menggariskan adanya keharusan untuk melaksanakan pendaftaran tanah diseluruh indonesia.

Kenyataannya masih banyak orang yang menempati maupun membangun rumah diatas tanah yang bukan miliknya atau diatas tanah sengketa tanpa memiliki surat kepemilikan hak atas tanah bahkan yang membuat sertifikat diatas tanah yang bersertifikat. Dalam hal terjadi sengketa kepemilikan atas tanah, maka pihak yang merasa memiliki tanah akan berusaha keras memperjuangkan hak-haknya. Oleh sebab itu 
pemerintah juga harus menjalankan kepentingan terselenggaranya kesejahteraan umum bagi seluruh warga masyarakat. Dalam hal seperti itu, maka sengketa-sengketa tidakdapat dihindari tanpa ditangani secara sungguh-sungguh, apabila hal tersebut dibiarkan, maka akanmembahayakan kehidupan masyarakat, terganggunya tujuan negara serta program pemerintah itu sendiri.

Melihat persoalan tersebut di atas, penguasaan tanah merupakan masalah yang perlu mendapatkan penyelesaian termasuk pembangunan dan penghunian rumah diatas tanah bukan miliknya yang sering melahirkan sengketa pertanahan. Dasar yuridis yang tersedia seakan-akan belum mampu untuk meredam konflik tersebut sehingga dibutuhkan pemikiranpemikiran untuk mencari solusi dalam pengaturan masalah hukumnya, maupun dalam hal penyelesaian sengketa. Provinsi Kalimantan Tengah kasus mengenai sengketa tanah terdata di Polda Kalimantan Tengah ada 7 kasus yang terjadi baik bidangperkebunan maupun kehutanan. Rinciannya masih banyak kasus perkebunan, yaitu satu kasus perambahan hutan, dan enam lainnya sengketa tanah perkebunan.8 kasus khusus di Kota Palangkaraya kasus sengketa tanah yang terjadi pada tahun 2013 ada 29 kasus yang rinciannya 18 kasus terjadi antara masyarakat dengan masyarakat itu sendiri, kemudian 4 kasus terjadi antara masyarakat dengan pihak pemerintah dan 7 kasus sisanya antara masyarakat dengan swasta.

Dari penjelasan diatas, merupakan sengketa tanah yang diselesaikan oleh Badan Pertanahan Nasional Kota Palangkaraya. Sengketa tanah yang sering terjadi lebih banyak melibatkan masyarakat dengan masyarakat terutama pada tahun $201 \mathrm{I}$ dengan jumlah kasus 45 kasus. Sedangkan pada tahun 2010 adalah jumlah sengketa paling sedikit dengan jumlah 4 kasus saja. Faktor terjadinya sengketa tanah antara masyarakat yaitu sertifikat tanah yang ganda, ini artinya kedua pihak sama-sama mempunyai sertifikat dengan pengesahan yang jelas pula. Salah satu contoh kasus sengketa tanah yang terjadi adalah kasus sengketa tanah yang melibatkan seorang warga Kota Palangkaraya yaitu Yohanes Arnold Pisy dengan pihak lain. Dalam hal ini Yohanes sebagai pemilik tanah secara sah menggugat salah satu pihak dengan alasan mengklaim kepemilikan tanahnya. Faktor yang menjadikan sengketa tanah tersebut ialah tumpang tindihnya 7 kepemilikan. Akan tetapi karena Yohanes punya surat-surat resmi akhirnya mendapat pengakuan dari camat dan lurah.Sehingga Yohanes pun bisa membayar tunggakan PBB di Bank Kalteng untuk mengamankan lahan miliknya di lokasi tersebut agar tidak diklaim oleh pihak lain, karena bukti atau resi pembayaran PBB bisa dijadikan sebagai alat untuk memperkuat kepemilikan lahannya tersebut selain bukti surat kepemilikan lahan yang telah disahkan oleh lurah dan camat terutama Surat keterangan tanah (SKT).

\section{METODOLOGI}

Jenis Penelitian Penelitian ini menggunakan pendekatan deskriptif kualitatif, dengan alasan agar dapat menggali informasi yang mendalam mengenai objek yang diteliti dalam hal ini esksistensi damang kepala adat dalam menyelesaikan sengketa tanah adat di Kota Palangkaraya. Metode deskriptif sebagai prosedur pemecahan 21 masalah yang di teliti berdasarkan fakta-fakta yang ada, sehingga tujuan dari metode deskriptif adalah menggambarkan suatu penyelesaian sengketa tanah adat.

Maka dari itu metode yang dilakukan adalah metode kualitatif dengan pendekatan deskriptif, yang bisa dipahami sebagai serangkaian prosedur yang digunakan dalam upaya pemecahan masalah yang diselidiki dengan menggambarkan atau melukiskan obyek penelitian. Sumber Data Dalam penelitian ini penulis memperoleh sumber data yang digunakan adalah:

a. Data Primer Data primer merupakan data yang didapatkan dari narasumber yang dianggap tahu terhadap persoalan yang terjadi. Data primer 
digunakan sebagai informasi penunjang penelitian supaya bisa memperkuat data informasi penulis dalam menyusun basis penelitian. Tujuan dalam data sekunder ini yaitu para informan atau para sumber yang berkaitan langsung dengan permasalahan penulisan yaitu Damang Kepala Adat.

b. Data Sekunder Data sekunder di butuhkan untuk melengkapi data primer untuk mengkaitkan langsung dengan persoalan sengketa tanah. Data sekunder didasarkan terhadap buku-buku, artikel, arsip, peraturan-peraturan yang berkaitan dengan sengketa tanah di Kota Palangkaraya.

Lokasi penelitian di maksudkan agar peneliti mampu mengungkapkan fakta supaya mendapatkan data dan informasi yang dibutuhkan oleh peneliti. Adapun lokasi penelitian yang dipilih adalah di Kecamatan Sebangau, Kota Palangkaraya. Teknik Pengumpulan Data Pada prinsipnya pengumpulan data empirik diawali dengan memahami setting. Dalam hal ini peneliti masuk sebagai bagian dari subyek penelitian. Sehubungan hal tersebut, maka digunakan teknik pengumpulan data berupa pengamatan, wawancara dan dokumentasi:

a. Wawancara Metode wawancara yaitu metode pengumpulan data dengan melalui perbincangan langsung. Perbincangan langsung dilakukan oleh peneliti dan yang menjadi narasumber dalam wawancara yaitu Damang Kepala Adat. Jadi hal ini dilakukan untuk mendapatkan informasi yang diingikan peneliti. Teknik ini dilakukan secara terstruktur dan berpartisipasi langsung dengan tujuan peneliti mendapatkan data-data yang diinginkan sesuai dengan kebutuhan peneliti. Dalam wawancara juga akan membahas Eksistensi Damang Kepala Adat Dalam Penyelesaian Konflik Agraria serta proses penyelesaiannya.

b. Metode Observasi Metode observasi yaitu pengumpulan data dengan cara melakukan pengamatan langsung terhadap obyek yang di teliti. Dalam hal ini penulis mengamati faktor-faktor yang menyebabkan sengketa tanh berdasarkan data dari 23 Badan
Pertanahan Nasional serta Damang Kepala Adat. Selain itu juga pengamatan langsung peneliti pada saat proses konflik di Peradilan Adat.

c. Metode Dokumentasi Metode dokumentasi yaitu pengumpulan data dengan cara melalui tulisan-tulisan mengenai hukum adat, peradilan, buku-buku tentang pedoman peradilan adat serta peraturan-peraturan mengenai hak-hak di atas tanah adat, tentang fungsi dan peran damang.

Data Teknik analisis data merupakan bagian yang sangat penting dalam metode ilmiah karena dengan analisis data dapat diberi arti tentang makna yang berguna dalam memecahkan permasalahan penelitian. Untuk analisis data peneliti menggunakan teknik analisis data kualitatif, analisis kualitatif terdiri dari:

a. Pengumpulan Data Dalam hal ini peneliti mencari dan mengumpulkan semua data yang ada di lapangan sesuai dengan judul penelitian, untuk kemudian dijadikan sebagai tambahan dalam penulisan.

b. Reduksi Data Merupakan proses penyajian,kompilasi daata setelah direduksi ke dalam bentuk-bentuk simbol yang bisa mengganbarkan keseluruhan datadata utamanya hasil penelitian. Kegiatan ini merupakan penyederhanaan data yang kompleks ke dalam, narasinarasi pendek sesuai kriteria dan klasifikasi data berdasarkan rumusan masalah sehingga dengan mudah bisa dipahami maknanya.

c. Display Data Merupakan tahap seleksi data atas data atau catatan-catatan lapangan seperti proses penyelesaian sengketa tanah,proses pengadilan adat,serta kendala dalam penyelesaian sehingga data yang didapat sesuai dengan pokok yang dituju dalam penelitian.

d. Verifikasi Data Setelah data disajikan, maka diambil beberapa alternatif yang sesuai dengan judul penelitian untuk dijadikan bahan penyampaian informasi dan pengambilan keputusan guna kemudian diambil sebuah kesimpulan. 
Pemeriksaan Keabsahan Data Untuk menguji keabsahan data yang dikumpulkan, peneliti akan menggunakan teknik triangulasi, yaitu teknik pemeriksaan data yang memanfaatkan sumber data yang lain diluar data itu untuk keperluan perbandingan atau pengecekkan derajat hasil penenlitian. Teknik triangulasi yang banyak digunakan adalah pemeriksaan melalui sumber lain. Dalam metode pemeriksaan data ini prbandingan antara data dan hasil pengamatan dengan wawancara dengan data dokumentasi, membandingkan data hasil penelitian dengan hasik penelitian-penelitian yang sebelumnya yang dianggap relevan, dengan membandingkan data hasil penelitian dengan teori.

\section{HASIL DAN PEMBAHASAN}

Dalam kasus perdata ini,identitas penggugat adalah bernama Susane Pikat Mahar, yang bertempat tinggal di Jalan Rajawali VII, no.0lab Kelurahan Bukit Tunggal, Kecamatan Jekan Raya Kota Palangka Raya. Penggugat adalah pemegang Surat Keterangan Tanah (SKT). Dalam kasus ini, identitas tergugat adalah bernama Adi Asmita yang bertempat tinggal di jalan DI.Panjaitan No.10 Kota Palangka Raya. Tergugat adalah pemegang Sertipikat.

Awal mula sejarah tanah yang bersengketa adalah tanah garapan yang dimiliki oleh lbu Susane Pikat Mahar (penggugat). Dari hasil wawancara, pernyataan dari lbu Susane Pikat Mahar tentang sejarah tanah yang bersengketa adalah :

" awal mula petak jituh tuh asal ah petak garapan, nyelu 1980 aku jadi menggarap ah. Aku parasih dengan bakabun melai petak jituh mangat uluh katawa bahwa petak jituh tege tempu. Nyelu 1980 te kea aku manampa SKT petak jituh. Ukuran petak tuh panjang 40 meter, lebar 30 meter, dan luas I.200 Meter. Batas-batas petak jituh sila Utara : jalan, sila Timur : Supriady, sila Selatan : Marduniaty Datang, dan sila Barat : Jalan.

Kendala petak jituh bihin nah pas nyelu 2002 aku handak manampa sertipikat akan Badan Pertanahan, ternyata batal awi ewen pertanahan permohonan kuh manampa sertipikat nah awi senga tege Adi Asmita (tergugat) mengaku bahwa iye pemilik asli petak jituh. Dan kea ternyata Adi Asmita (tergugat) jadi manampa sertipikat ayu nyelu 1994, ternyata sertipikat ayu Adi Asmita (tergugat) jadi gadai ah melai Bank Tabungan
Nasional (BTN) cabang Palangka Raya. Awi iye dia tau mambayar tagihan melai bank, jadi ewen bank manampa iklan melai koran bahwa petak ayung kuh nah lelang melai koran.

Setelah aku katawa bahwa Adi Asmita (terguugat) manampa sertipikat diatas petak ayung kuh, aku langsung melapor akan kepolisian sektor pahandut. Aku malapor Adi Asmita (tergugat) dengan tuduhan pemalsuan sertipikat, awi Adi Asmita (tergugat) mensertipikat petak ayung kuh tanpa hak sehingga diterbitkan sertipikat hak milik ( SHM ) Nomor 4092 dengan luas petak 860 meter dan sertipikat petak jite jadi gadai akan bank.

Limbah aku melapor akan polisi, Adi Asmita (tergugat) dipanggil awi ewen kepolisian tapi iye dia puji dumah. Ternyata tanggal 23 April 2002, Adi Asmita (tergugat) mengajukan surat perjanjian damai akang kuh, iye menyerahkan petak jituh akang kuh dengan catatan aku mencabut laporan kuh melai kantor polisi. Jadi aku mencabut laporan kuh melai kantor polisi dan ikei sepakat berdamai.

Limbah ikei damai,senga tege uluh mengaku bahwa petak jituh jadi jual Adi Asmita akan Salihun. Pas aku handak parasih petak jituh senga tege Salihun mengaku bahwa petak jituh ayu ah. Awi aku dia terima Salihun mengaku petak jituh ayu ah, aku dengan Salihun mengadu akan Pertanahan dan aku manenga surat perjanjian damai je jadi nenga Adi Asmita akang kuh tentang petak jituh.

Jadi ewen pertanahan nah langsung muhun ih akan lapangan meukur petak jituh,aku dengan Salihun dengan Adi Asmita nah umba kea akan lapangan mangat ikei uras katawa kebenaran ah petak jituh. Limbah ewen pertanahan meukur petak jituh ternyata ukuran petak je tege melai keterangan sertipikat ayun Adi Asmita nah dia sesuai dengan ukuran petak je tege melai lapangan, sedangkan melai surat petak ayung kuh ukuran dengan batas-batas petak te sesuai dengan je tege melai lapangan. Setelah ewen pertanahan muhun lapangan dan meukur petak jituh, ewen pertanahan mengatakan bahwa surat petak je asli adalah surat petak ayung kuh sedangkan surat petak ayun Adi Asmita nah palsu awi ukuran dan letak ah dia sesuai dengan je tege melai lapangan. Limbah jite nah Adi Asmita dengan Salihun mengatakan bahwa petak jituh puna petak ayung kuh. Limbah kejadian jite Adi Asmita mengajukan damai hindai akang kuh dan iye balaku maaf dan kea iye mengakui bahwa sertipikat petak ayu ah memang palsu.

\section{Terjemahan :}

"awal mula sejarah tanah ini adalah tanah garapan pada tahun 1980,saya mulai menggarap tanah ini pada tahun 1980. Saya merawat dan membersihkan tanah ini agar orang-orang mengetahui bahwa tanah ini ada pemiliknya,di tahun 1980 saya juga membuat SKT atas tanah ini. Tanah ini berukuran panjang : 40 meter,lebar : 30 meter,dan luas : 1.200 meter. Batas-batas pada tanah ini yaitu di sebelah utara : jalan,di sebelah timur : Ssupriady,di sebelah selatan : Marduniaty Datang,dan di sebelah barat : jalan. 
Kendala yang terjadi pada tanah ini yaitu pada tahun 2002,saat saya ingin membuat Sertipikat Hak Milik (SHM) ke Badan Pertanahan tiba-tiba Adi Asmita mengakui bawha tanah yang saya miliki adalah tanah yang ia miliki, karena Adi Asmita mengaku tanah tersebut adalah miliknya Badan pertanah pun membatalkan pembuatan sertipikat saya. Ternyata Adi Asmita sudah membuat sertipikat tanah tersebut pada tahun 1994,dan sertipikat tanah tersebut sudah digadai oleh Adi Asmita ke Bank Tabungan Nasional (BTN) cabang Palangka Raya. Karena Adi Asmita tidak bisa membayar tagihan di Bank tersebut,jadi pihak Bank melelang tanah tersebut di koran.

Setelah saya mengetahui bahwa Adi Asmita sudah membuat sertipikat diatas tanah milik saya,saya langsung melaporkan Adi Asmita ke kepolisian sektor pahandut Palangka Raya. Saya melaporkan Adi Asmita dengan tuduhan pemalsuan,penyerobotan dan penggelapan tanah,karena yang bersangkutan sudah mensertipikat tanah milik saya tanpa hak sehingga diterbitkan Sertipikat Hak Milik (SHM) Nomor 4092,luas 860 M2. Yang mana sertipikat tersebut sudah di gadai ke Bank Tabungan Nasional (BTN) Palangkaraya. Sesudah saya melaporkan Adi Asmita kepolisi, pihak kepolisian pun memanggil Adi Asmita untuk dimintai keterangan tentang laporan saya,tetapi Adi Asmita tidak pernah menghadiri panggilan kepolisian tersebut. Ternyata pada tanggal 23 April 2002,Adi Asmita mengajukan surat perjanjian damai kepada saya dan didalam surat perjanjian damai tersebut Adi Asmita bersedia menyerahkan tanah tersebut kepada saya dengan kesepakatan saya bersedia untuk mencabut laporan saya di kepolisian. Saya dan Adi Asmita pun bersepakat untuk damai pada tanggal 23 April 2002.

Kemudian pada tahun 2010 saat saya ingin membersihkan tanah tersebut, tiba-tiba ada seseorang (Salihun) yang mengaku bahwa sudah membeli tanah tersebut dari Adi Asmita. Karena saya tidak terima dengan pengakuan Salihun, saya bersama Salihun pun membuat pengaduan ke Badan Pertanahan Kota Palangka Raya dan di Pertanahan saya juga menjelaskan bahwa tanah milik saya sudah dijual oleh Adi Asmita kepada Salihun, kemudian saya juga memberikan bukti surat pejanjian damai tahun 2002 tentang tanah tersebut yang dusah diberikan Adi Asmita kepada saya.

Setelah menerima pengaduan,pihak pertanahan pun melakukan penelitian dengan melakukan pengukuran ulang di tanah tersebut untuk memastikan letak dan ukuran yang diakui oleh Salihun yang beli dari Adi Asmita dan pada saat pengukuran pun dihadiri langsung oleh Salihun dan Adi Asmita. Pada saat pengukuran yang di lakukan oleh piha pertanahan, keterangan letak dan ukuran tanah yang terdapat di sertipikan milik Adi Asmita yang sudah di jual kepada Salihun terdapat kejanggalan, karena ukuran dan letak tanah pada sertipikat tersebut sama sekali tidak sesuai dengan yang ada dilapangan. Sedangkan dilihat dari Surat tanah (SKT) yang saya miliki,ukuran dan letak tanah pun sesuai dengan keterangan yang ada,dan saya dapat menjelaskan dengan jelas asal usul dan batasbatas yang terdapat pada tanah tersebut.

Karena pihak pertanahan sudah melihat langsung lokasi dan surat-surat tanah tersebut,pihak pertanahan pun langsung mengatakan bahwa surat tanah (SKT) yang saya miliki adalah surat tanah yang jelas dan benar,sedangkan surat tanah yang dimiliki oleh Adi Asmita tidak memiliki kejelasan dan keterangan letak dan ukuran yang ada pada surat tanah tersebut tidak sesuai dengan tanah yang sudah di ukur oleh pihak pertanahan. Saat musyawarah Adi Asmita juga mengakui bahwa sertipikat tanah miliknya tidak fiktip dan memang tidak memiliki ukuran yang jelas. Adi Asmita kembali membuat perdamaian dan meminta maaf atas kesalahannya.

Setelah adanya sengketa tersebut,saya langsung membuat Sertipikat Hak Milik (SHM) atas tanah tersebut,yang mana langsung diproses oleh Badan Pertanahan Nasional Kota Palangka Raya."

Dari permasalahan diatas maka diajukanlah gugatan yaitu:

I. Penggugat yaitu lbu Susane Pikat Mahar adalah pemilik dari Surat Keterangan Tanah (SKT) yang dibuat pada tahun 1980, penggugat mengaku tanah yang ada di jalan Rajawali VII Kota Palangka Raya adalah miliknya. Tanah tersebut berukuran :

$\begin{array}{ll}\text { Panjang } & : 40 \text { meter } \\ \text { Lebar } & : 30 \text { meter } \\ \text { Luas } & : 1.200 \text { meter } \\ \text { Dengan batas-batas tanah : } & \\ \text { Sebelah utara } & : \text { jalan } \\ \text { Sebelah timur } & : \text { Supriady } \\ \text { Sebelah selatan } & : \text { Marduniaty Datang } \\ \text { Sebelah barat } & : \text { jalan }\end{array}$

2. Pada tahun 2002 penggugat ingin mensertipikat tanah tersebut ke Badan Pertanahan kota Palangka Raya,namun pihak pertanahan membatalkan permohonan penggugat dikarenakan ada seseorang yang bernama Adi Asmita (tergugat) yang mengaku pemilik asli tanah tersebut dan tergugat memiliki bukti surat tanah berupa sertipikat.

3. Adi Asmita (tergugat) membuat sertipikat hak milik atas tanah tersebut pada tahun 1994,dengan nomor sertipikat 4092. Selain itu Adi Asmita (tergugat) telah menggadai sertipikat tanah tersebut kepada Bank Tabungan Nasional (BTN). 
4. Setelah merasa dirugikan, Susane Pikat Mahar (penggugat) melaporkan Adi Asmita (tergugat) ke kepolisian sektor pahandut pada tanggal 26 Maret 2002 dengan perihal laporan pengaduan tentang pemalsuan,penyerobotan dan penggelapan tanah.

5. Setelah Susane Pikat Mahar (penggugat) melaporkan Adi Asmita (tergugat) ke polisi,tergugat mendapat panggilan untuk memberikan keterangan tentang laporan yang diajukan oleh penggugat,tetapi Adi Asmita (tergugat) tidak pernah menghadiri panggilan dari pihak kepolisian.

6. Ternyata pada tanggal 23 April 2002, Adi Asmita (tergugat) mengajukan surat permohonan damai kepada Susane Pikat Mahar (penggugat). Didalam surat perjanjian damai tersebut Adi Asmita (tergugat) bersedia menyerahkan tanah tersebut tanpa syarat dan didalam surat perjanjian yang diberikan oleh Adi Asmita dituliskan bahwa Susane Pikat Mahar bersedia mencabut laporan di Polresta Palangka Raya No.Pol. K/I60/III/2000/ pamapta, tanggal 26 Maret 2002 serta menganggap perkara telah diselesaikan secara damai.

7. Setelah Susane Pikat Mahar (penggugat) melakukan perdamaian secara kekeluargaan dengan Adi Asmita (tergugat),di tahun 2010 ada seseorang yang bernama Salihun mengaku pemilik tanah tersebut dan Salihun mengatakan mendapat tanah tersebut dibeli dari Adi Asmita.

8. Penggugat (Susane Pikat Mahar) kembali membuat pengaduan ke Badan Pertanahan Kota Palangka Raya untuk membuktian surat dan pemilik tanah yang asli.

9. Setelah menerima pengaduan dari Susane Pikat Mahar (penggugat), pihak pertanahan langsung melakukan pengukuran di tanah tersebut. Pada saat dilakukan pengukuran, dihadiri langsung oleh Susane Pikat Mahar (penggugat), Adi Asmita (tergugat), dan Salihun (orang yang membeli tanah tersebut dengan Adi Asmita).
10. Pihak pertanahan mengukur langsung tanah tersebut, saat dilakukan pengukuran terdapat kejanggalan yang ada di Sertipikat milik Adi Asmita (tergugat). Kejanggalan tersebut yakni ukuran dan batas-batas tanah yang ada di sertipikat milik Adi Asmita tidak sesuai dengan yang ada di lapangan.

I I. Sedangkan ukuran dan batas-batas tanah yang ada didalam Surat Keterangan Tanah (SKT) yang dimiliki oleh Susane Pikat Mahar (penggugat) ukuran dan batas-batas tanah sesuai dengan yang ada dilapangan.

12. Karena ada bukti-bukti dari pengukuran yang dilakukan pihak pertanahan,Adi Asmita (tergugat) dan Salihun mengakui bahwa tanah tersebut adalah milik dari Susane Pikat Mahar (penggugat) dan Adi Asmita (tergugat) memohon maaf dan meminta perdamaian kembali kepada Susane Pikat Mahar.

13. Pihak pertanahan mengatakan bahwa Surat Keterangan Tanah (SKT) yang dimiliki oleh Susane Pikat Mahar adalah surat sah dari kepemilikan tanah tersebut, sedangkan Sertipikat yang dimiliki oleh Adi Asmita dinyatakan sertipikat Palsu.

Setelah Badan Pertanahan melakukan penelitian di lapangan dan membandingan keterangan yang ada disurat tanah milik Penggugat dan tergugat, Badan Pertanahan mengatakan bahwa surat tanah yang dimiliki oleh tergugat adalah surat tanah palsu,sedangkan surat tanah yang dimiliki oleh penggugat adalah surat tanah yang asli. Adi Asmita selaku tergugat mengakui bahwa surat tanah yang dimiliki Susane Pikat Mahar selaku Penggugat adalah surat tanah yang sah dan tergugat meminta perdamaian kepada penggugat dan bersedia bertanggung jawab terhadap kerugian yang di alami oleh Salihun. Perdamaian dilakukan secara kekeluargaan.

Dalam kasus diatas, yang dapat dilakukan di Badan Pertanahan Nasional (BPN) adalah memfasilitasi dalam Mediasi/Musyawarah. Badan Pertanahan Nasional berperan sebagai tempat mediasi atau tempat 
menyelesaikan sengketa secara kekeluargaan tanpa melewati pengadilan.

Badan Pertanahan Nasional (BPN) juga berperan sebagai pemeriksa lapangan terhadap tanah yang bersengeta. Kegiatan pemeriksaan lapangan dapat dilakukan oleh pejabat yang berwenang yang disertai dengan surat tugas. Kegiatan pemeriksaan lapanganan meliputi :

I. Penelitian atas kesesuaian data dengan kondisi lapangan.

2. Pencarian keterangan dari saksi-saksi atau pihakpihak yang terkait.

3. Penelitian batas bidang tanah,gambar ukur, peta bidang tanah, gambar situasi/surat ukur.

4. Kegiatan lainnya yang diperlukan dalam pemeriksaan lapangan.

Setelah melakukan pemeriksaan lapangan, Badan Pertanahan Nasional dapat menyelesaikan sengketa dengan menerbitkan :

I. Keputusan pembatalan hak atas tanah

2. Keputusan pembatalan sertipikat

3. Keputusan perubahan data pada sertipikat, surat ukur, buku tanah dan daftar umum lainnya.

4. Surat pemberitahuan bahwa tidak terdapat kesalahan administrasi.

Keputusan pembatalan hak atas tanah merupakan pembatalan terhadap hak atas tanah, tanda bukti hak dan daftar umum lainnya yang berkaitan dengan hak tersebut.

Dalam kasus diatas, dalam hal diatas satu bidang tanah terdapat tumpang tindih sertipikat hak atas tanah, Kepala Kantor Badan Pertanahan Nasional (BPN) sesuai kewenangannya menerbitkan keputusan pembatalan sertipikat yang tumpang tindih, sehingga diatas satu bidang tanah tersebut hanya ada satu (I) sertipikat hak atas tanah yang sah.

\section{KESIMPULAN}

Dari pembahasan ditarik kesimpulan bahwa penyelesaian sengketa yang dapat dilakukan di Badan
Pertanahan Nasional Kota Palangka Raya adalah memfasilitasi dalam mediasi/musyawarah. Badan Pertanahan Nasional juga berperan sebagai tempat mediasi atau tempat menyelesaikan sengketa secara kekeluargaan tanpa melewati pengadilan dan berperan sebagai pemeriksa lapangan terhadap tanah yang bersengketa.

\section{UCAPAN TERIMA KASIH}

Terima Kasih diucapkan kepada Ibu Susane Pikat Mahar, Adi Asmita, Salihun, dan Badan Pertanahan Kota Palangka Raya karena telah membantu memberikan informasi dalam penyusunan penelitian ini.

\section{REFERENSI}

Ali Chomzah, Hukum Pertanahan Seri Hukum Pertanahan I Pemberian Hak Atas Tanah Negara Dan Seri Hukum Pertanahan II Sertipikat dan Permasalahannya (Jakarta, 2002)

AP. Parlindungan, Pendaftaran Tanah Tanah dan Konfersi hak milik atas tanah menurut UUPA(Bandung,Alumni, 1988),

Boedi Harsono, Hukum Agraria Indonesia, Sejarah Pembentukan UUPA, Isi dan Pelaksanaannya (Jakarta; Djambatan, 2005)

Bachtiar Effendie, Pendaftaran Tanah Dilndonesia Dan Peraturan Pelaksanaannya( Bandung; Alumni, 1993)

Eddy Ruchiat, Politik Pertanahan Sebelum dan Sesudah Berlakunya UUPA No.5 Tahun 1960 (Bandung, 1995)

Efendi Perangin, Praktek Pengurus Sertipikat Hak Atas Tanah, (Jakarta, 1966)

Florius SP Sangsun, Tata Cara Mengurus Sertipikat Tanah, (Jakarta, 2007)

Rusmadi Murad, Penyelesaian Sengketa Hukum Atas Tanah

R. Subekti, Hukum Pembuktian, Pradnya Paramita, Jakarta 200 I

Urip Santoso , S.H.,M.H, Hukum Agraria dan Hak-Hak Atas Tanah, (Surabaya, 2005).

Supranowo, Sertipikat dan Permasalahannya, (Yogyakarta, 1992)

Wantjik Saleh, Hak Anda Atas Tanah (Jakarta, 1997) 